\title{
Efficient synthesis of an (aminooxy) acetylated-somatostatin derivative using (aminooxy)acetic acid as a 'carbonyl capture' reagent
}

\author{
Gábor Mezö, ${ }^{a *}$ Ildikó Szabó, ${ }^{a, b}$ István Kertész, ${ }^{c}$ Rózsa Hegedüs, ${ }^{\text {a,b }}$ \\ Erika Orbán, ${ }^{\text {a,b }}$ Ulrike Leurs, ${ }^{d}$ Szilvia Bösze, ${ }^{a}$ Gábor Halmos ${ }^{e}$ \\ and Marilena Manea ${ }^{d, f *}$
}

Owing to the high chemoselectivity between an aminooxy function and a carbonyl group, oxime ligation is one of the most preferred procedures for the preparation of peptide conjugates. However, the sensitivity of (aminooxy)acetylated peptides to ketones and aldehydes makes their synthesis and storage difficult. In our study, we established the efficient synthesis of an (aminooxy)acetylated-somatostatin derivative in the presence of free (aminooxy)acetic acid, which was used as a 'carbonyl capture' reagent in the final cleavage step. This (aminooxy)acetylated compound was further used for the chemoselective ligation (oxime bond formation) with daunorubicin and 4-fluorobenzaldehyde leading to the formation of conjugates with potential applications in targeted cancer chemotherapy and positron emission tomography. Copyright $(\mathcal{C}) 2010$ European Peptide Society and John Wiley \& Sons, Ltd.

Keywords: (aminooxy)acetic acid; somatostatin; chemical ligation; oxime bond formation; peptide conjugates; carbonyl capture reagent; drug targeting

\section{Introduction}

Chemoselective ligation methods are commonly used for the preparation of peptide conjugates, as well as for the condensation of unprotected peptide fragments. Oxime ligation is one of the most preferred procedures, due to the high chemoselectivity between an aminooxy function and a carbonyl group [1,2]. Formation of chemoselective oxime bonds has been successfully applied for the synthesis of various peptide conjugates [3,4], glycopeptides [5], conjugates of DNA with different biomolecules [6], oligonucleotide-peptide conjugates $[7,8]$, and proteins from peptide fragments $[9,10]$. Moreover, oxime ligation has recently been investigated for the preparation of ${ }^{18} \mathrm{~F}$-labeled peptide conjugates [11,12] and drug-peptide conjugates [13-15]. Furthermore, (aminooxy)acetic acid was incorporated into heterobifunctional linkers for facile synthesis of bioconjugates $[16,17]$.

During the past decade, several side reactions have been reported to occur during synthesis, purification, and work-up procedures of (aminooxy)acetylated peptides $[9,10,18]$. One of them is the $\mathrm{N}$-overacylation of the $\mathrm{NH}-\mathrm{O}$ function, either during the incorporation of Boc-(aminooxy)acetic acid derivative (BocAoa) or through the peptide chain elongation. Carbodiimidemediated one-pot acylation without base [18] or the application of Boc-Aoa-OSu active ester as an acylating agent [19], as well as the use of a high excess ( 8 equiv.) of Boc- $\mathrm{Aoa}-\mathrm{OH}$ and coupling agents for a short acylation time (10 $\mathrm{min})$ [20] might prevent the overacylation.

Another side reaction which has been less investigated and reported so far derives from the high reactivity of the free aminooxy group toward aldehydes and ketones leading to the formation of unwanted side products [9]. (Aminooxy)acetylated peptides can react with traces of acetone or formaldehyde (e.g. from the softeners of the plastic tubes) not only during the reaction steps (cleavage, ligation) but also under the HPLC purification conditions and even during the storage of the purified peptides. Buré et al. identified the main side products that were formed during oxime ligation of peptides [10]. Using

\footnotetext{
Correspondence to: GáborMezö, Research Group of Peptide Chemistry, Hungarian Academy of Sciences, Eötvös L. University, 1117 Budapest, Pázmány P.stny.1/A, Hungary.E-mail: gmezo@elte.hu

MarilenaManea, University of Konstanz, Zukunftskolleg and Depart ment of Chemistry, Laboratory of Analytical Chernistry and Biopolymer Structure Analysis, Universitätsstrasse 10, 78457 Konstanz, Germany. E mail:marilena.manea@uni-konstanz.de

a Research Group of Peptide Chemistry, Hungarian Academy of Sciences, Eötvös Loránd University, 1117 Budapest, Hungary

b Institute of Chemistry, Eötvös Loránd University, 1117 Budapest, Hungary

c Department of Nuclear Medicine, Medical and Health Science Center, University of Debrecen, 4032 Debrecen, Hungary

d Laboratory of Analytical Chemistry and Biopolymer Structure Analysis, Department of Chemistry, University of Konstanz, 78457 Konstanz, Germany

e Department of Biopharmacy, University of Debrecen, 4032 Debrecen, Hungary

f Zukunftskolleg, University of Konstanz, 78457 Konstanz, Germany
} 
liquid chromatography-tandem mass spectrometry (LC-MS/MS), ions corresponding to products having $-15,+12,+26,+40$, and $+96 \mathrm{Da}$ difference than the calculated mass of the conjugate were detected. These ions corresponded to the $\mathrm{NH}_{2}$ loss $\left(\mathrm{H}_{2} \mathrm{~N}\right.$ $\mathrm{O}-\mathrm{R}$ to HO-R), to conjugates with formaldehyde, acetaldehyde, acetone, and to trifluoroacetylated compounds, respectively. To overcome this problem, the use of Boc-Aoa-peptide precursors for chemical ligation in combination with in situ Boc cleavage was suggested [12]. The efficiency of the in situ Boc cleavage during the labeling reactions was demonstrated in the case of the synthesis of $\left[{ }^{18} \mathrm{~F}\right] \mathrm{FBOA}$-peptides [11] and of a templateassembled cyclic RGD peptide conjugate [21]. However, it was mentioned that a fivefold higher peptide concentration was needed for the efficient labeling in comparison with the unprotected (aminooxy)acylated peptides. Careful handling of unprotected Aoa-containing peptides, such as working under argon or nitrogen stream in an 'acetone-free' laboratory, using freshly distilled diethylether for precipitation [22], shortening the work-up procedure, using methanol or freshly prepared acetonitrile solutions for HPLC purification, and storage of the compounds at temperatures below $-20^{\circ} \mathrm{C}$ in glass tubes might help avoid the unwanted side reactions. However, in some cases all of these precautions are not enough to prevent the formation of a large amount of side products.

In the present study, we provide evidence that free (aminooxy)acetic acid could serve as an efficient 'carbonyl capture' reagent if it is added to the cleavage mixtures used for the cleavage of (aminooxy)acetylated peptides from the resin. We employed this 'carbonyl capture' reagent for the synthesis of an (aminooxy)acetylated-somatostatin derivative which was further used for the preparation of daunorubicin-somatostatin and FBOA-somatostatin bioconjugates.

Recently, we have demonstrated the in vitro and in vivo antitumor activity of a daunorubicin - GnRH-III derivative bioconjugate (GnRH: gonadotropin-releasing hormone) containing an oxime linkage between the components [13]. The formation of a side product $(M+40 \mathrm{Da})$ was observed after the cleavage of the GnRH-III derivative (Glp-His-Trp-Ser-His-Asp-Trp-Lys(HAoa-Gly-Phe-Leu-Gly)-Pro-Gly-NH${ }_{2}$ ) from the resin. However, the (aminooxy)acetylated peptide could be purified and further used for the attachment of daunorubicin via oxime ligation. In contrast, the synthesis of H-Aoa-D-Phe-c[Cys-Tyr-D-Trp-Lys-Val-Cys]-Thr$\mathrm{NH}_{2}$, an $\mathrm{N}$-terminal Aoa-elongated version of $\mathrm{RC}-121$ somatostatin analog developed in Schally's laboratory [23] was unsuccessful. Several synthetic procedures were employed; however, none of them led to the formation of the desired cyclic peptide. In spite of the careful work, oximes of the somatostatin derivative with acetone, acetaldehyde, and formaldehyde were almost quantitatively formed. Finally, this highly sensitive (aminooxy)acetylated peptide could efficiently be prepared in the presence of free Aoa as a 'carbonyl capture' reagent which was used during the removal of the $\mathrm{N}$-terminal Boc protecting group.

\section{Materials and Methods}

\section{Chemicals}

All amino acid derivatives and Rink-Amide $\mathrm{MBHA}$ resin were purchased from IRIS Biotech GmbH (Marktredwitz, Germany) or Reanal (Budapest, Hungary). Scavengers, coupling agents, and cleavage reagents $\left[N, N^{\prime}\right.$-diisopropylcarbodiimide (DIC), 1,2-ethanedithiol (EDT), $\mathrm{N}$-diisopropyl-ethylamine (DIEA), 1-hydroxybenzotriazole
(HOBt), 1,8-diazabicyclo-[5.4.0]undec-7-ene (DBU), piperidine, trifluoroacetic acid (TFA)], pentachlorophenol ( $\mathrm{PcPOH})$ as well as daunorubicin (Dau), aminooxyacetic acid (Aoa), and Bocaminooxyacetic acid (Boc-Aoa-OH) were Fluka products (Buchs, Switzerland). Solvents used both for synthesis and HPLC purification [dichloromethane (DCM) $\mathrm{N}, \mathrm{N}$-dimethylformamide (DMF), ethyl acetate, and methanol ( $\mathrm{MeOH})$ ] were purchased from Molar Chemicals (Budapest, Hungary). HPLC grade acetonitrile (MeCN), 2,5-dihydroxy benzoic acid (DHB), and 4-fluorobenzaldehyde were from Sigma-Aldrich $\mathrm{Kft}$ (Budapest, Hungary).

\section{Synthesis of Boc-Aoa-OPcp (1)}

Boc-Aoa-OH and PcpOH (10 mmol each) were dissolved in $50 \mathrm{ml}$ ethyl acetate and then an equivalent amount of DCC in $50 \mathrm{ml}$ ethyl acetate was added to the solution (under cooling). The reaction mixture was stirred overnight at RT. The precipitated DCU was filtered out prior to the evaporation of the solvent. The remaining compound was recrystallized from methanol. The yield of the pure product was $72 \%$. Melting point: $165-166^{\circ} \mathrm{C}$. Elemental analysis: C 35.28 (calc. 35.50 ); H 2.78 (2.72); N 3.03 (3.18); Cl 40.49 (40.39).

\section{Synthesis of linear somatostatin derivative (H-D-Phe-Cys-Tyr-} D-Trp-Lys(ivDde)-Val-Cys-Thr-NH 2 , 2)

The linear somatostatin analog was synthesized manually on a Rink-Amide MBHA resin $(0.65 \mathrm{mmol} / \mathrm{g}$ coupling capacity) by $\mathrm{Fmoc} / \mathrm{t} \mathrm{Bu}$ strategy. The following Fmoc-protected amino acid derivatives were used: $\mathrm{Fmoc}-\mathrm{Thr}\left({ }^{\mathrm{H}} \mathrm{Bu}\right)-\mathrm{OH}, \mathrm{Fmoc}-\mathrm{Cys}(\mathrm{Trt})$ $\mathrm{OH}$, Fmoc-Val-OH, Fmoc-Lys(ivDde)-OH, Fmoc-D-Trp-OH, FmocTyr $\left({ }^{(} \mathrm{Bu}\right)-\mathrm{OH}$, and Fmoc-D-Phe-OH. The synthetic protocol was as follows:(i) DMF washing $(4 \times 1 \mathrm{~min})$; (ii) Fmoc deprotection with $2 \%$ DBU, $2 \%$ piperidine in DMF ( 4 times: $2+2+5+10 \mathrm{~min}$ ); (iii) DMF washing $(8 \times 1 \mathrm{~min})$; (iv) coupling of 3 equiv. of Fmoc-amino acid/DIC/HOBt in DMF (60 min); (v) DMF washing $(4 \times 1 \mathrm{~min})$; and (vi) ninhydrine assay. The peptide was cleaved from the resin using a mixture of TFA-phenol-EDT-thioanisole-water $(10 \mathrm{ml}$, $0.75 \mathrm{~g}, 0.25 \mathrm{ml}, 0.5 \mathrm{ml}, 0.25 \mathrm{ml}$ ) at RT for $1.5 \mathrm{~h}$, then precipitated with cold diethyl ether, washed three times with diethyl ether, and solubilized in $100 \%$ acetic acid prior to freeze drying. By this cleavage procedure, all side-chain protecting groups were removed except for the ivDde from the side chain of Lys. The crude peptide was characterized by analytical RP-HPLC (Rt:36.3 min) and

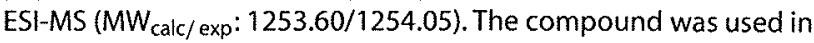
the next synthetic step without purification.

\section{Coupling of Boc-Aoa-OPcp to the semiprotected linear somatostatin derivative (Boc-Aoa-D-Phe-Cys-Tyr-D-Trp- Lys(ivDde)-Val-Cys-Thr-NH $\mathrm{NH}_{2}$ )}

Boc-Aoa-OPcp (1.5 equiv.) and H-D-Phe-Cys-Tyr-D-Trp-Lys(ivDde)$\mathrm{Val}-\mathrm{Cys}-\mathrm{Thr}-\mathrm{NH}_{2}$ (1 equiv.) were dissolved in DMF and then 1.5 equiv. DIEA was added to the reaction mixture. The coupling reaction was carried out at RT for 1 day. After removing the solvent, the peptide was dissolved in a mixture of eluent $A(0.1 \%$ TFA in water) and $B(0.1 \%$ TFA in acetonitrile-water $(80: 20, v / v)$ and purified by RP-HPLC. The application of Boc-Aoa-OPcp prevented the overacylation of the compound completely and the yield was $75 \%$. The purified compound was characterized by analytical RP-HPLC (Rt: $44.5 \mathrm{~min}$ ) and ESI-MS (MW/calc/exp: 1427.7/1427.4). 

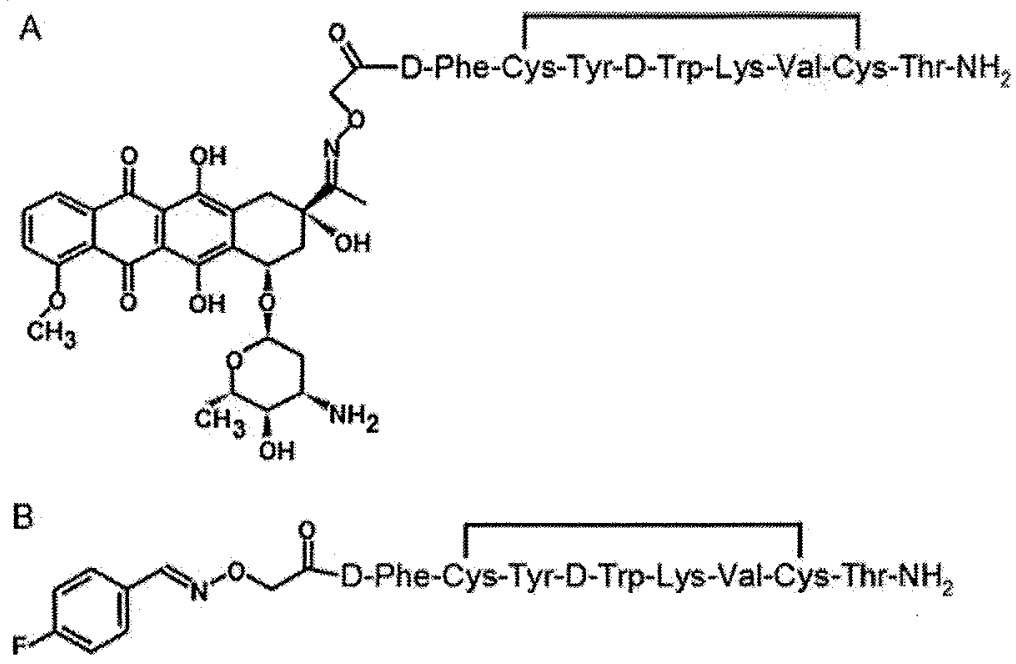

Figure 1. Structures of daunorubicin-somatostatin (A) and FBOA-somatostatin conjugates (B).
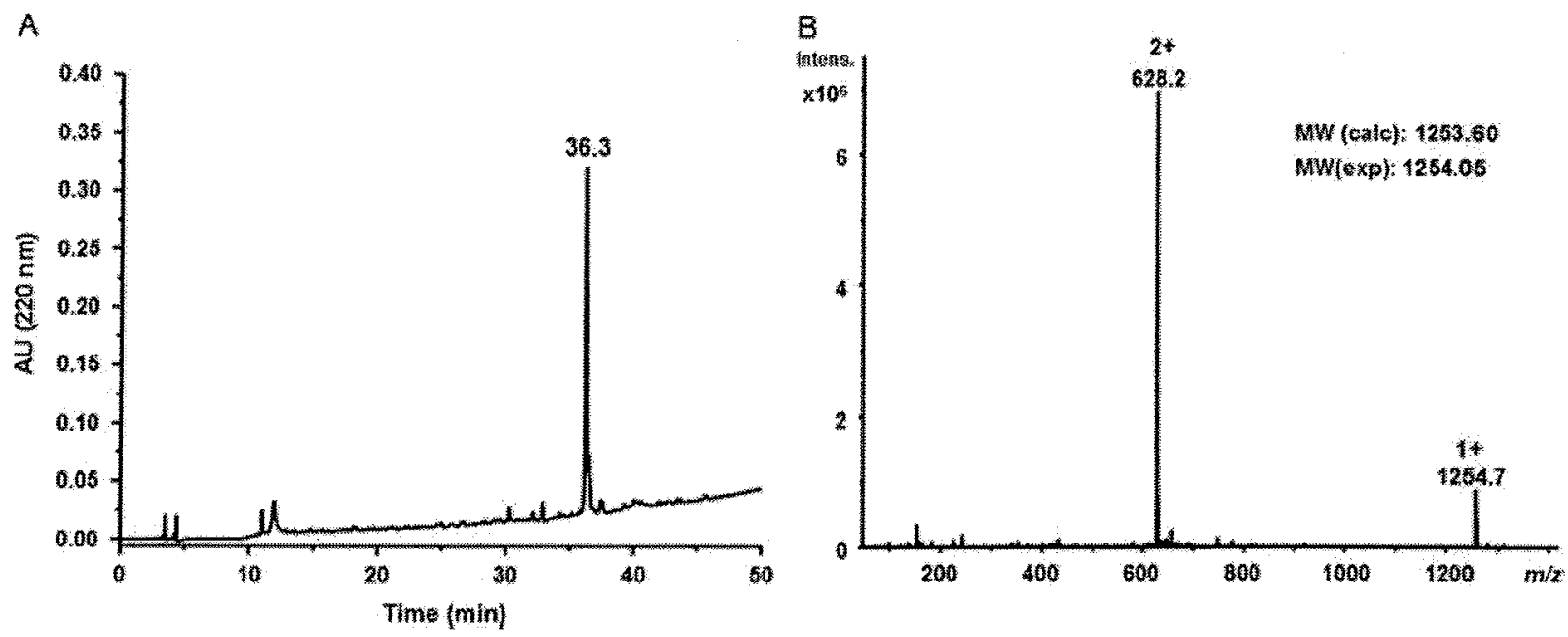

Figure 2. HPLC chromatogram (A) and ESI-ion trap mass spectrum of crude H-D-Phe-Cys-Tyr-D-Trp-Lys(ivDde)-Val-Cys-Thr-NH 2 (B).

\section{Simultaneous cleavage of ivDde protecting group and disulfide bond formation (Boc-Aoa-D-Phe- c[Cys-Tyr-D-Trp-Lys-Val-Cys]-Thr- $\mathrm{NH}_{2}$, 4)}

From the Boc-protected linear peptide, the ivDde group was cleaved with $2 \%$ hydrazine in DMF. Under these cleavage conditions (peptide concentration of $1 \mathrm{mg} / \mathrm{ml}, \mathrm{RT}, 60 \mathrm{~min}$ ), not only was the protecting group removed but the disulfide bridge between the thiol groups of cysteines was also formed. The solvent was evaporated in vacuo and the crude peptide was purified by semipreparative RP-HPLC (47\% yield). The purified compound was characterized by analytical RP-HPLC (Rt: $33.1 \mathrm{~min}$ ) and ESI-MS

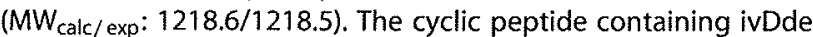
protecting group (Rt: $43.7 \mathrm{~min}$ ) and the unprotected linear peptide (Rt: $30.9 \mathrm{~min}$ ) were identified as main side products.

Boc removal in the presence of (aminooxy)acetic acid as a 'carbonyl capture' reagent (H-Aoa-D-Phe-ciCysTyr-D-Trp-Lys-Val-Cys]-Thr- $\mathrm{NH}_{2}, \underline{5}$ )

In order to prevent the side reactions by oxime formation, the Boc protecting group was removed from Boc-Aoa-D-Phe-c[Cys-
Tyr-D-Trp-Lys-Val-Cys]-Thr- $\mathrm{NH}_{2}$ with $95 \%$ TFA $-5 \% \mathrm{H}_{2} \mathrm{O}$ in the presence of 10 equiv. of free (aminooxy)acetic acid at RT for $30 \mathrm{~min}$. The mixture of cyclic peptide and Aoa was precipitated with diethylether, then the precipitate was redissolved in $100 \%$ acetic acid and lyophilized. The Boc-cleaved compound was characterized by analytical RP-HPLC (Rt: $26.4 \mathrm{~min}$ ) and ESI-MS

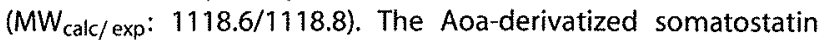
analog could be stored for several months at $4{ }^{\circ} \mathrm{C}$ in the presence of the 'carbonyl capture' reagent without detecting any modification. Prior to the oximeligation, the excess of Aoa was separated by HPLC or by using a Sep-Pak Plus C18 cartridge (Waters, Milford, MA).

Oxime ligation of daunorubicin (Dau) to Aoa-somatostatin derivative (Dau=Aoa-D-Phe-c[Cys-Tyr-D-Trp-Lys-Val-Cys]Thr- $\mathrm{NH}_{2}, \underline{6}$ )

The mixture of H-Aoa-D-Phe-c[Cys-Tyr-D-Trp-Lys-Val-Cys]-Thr$\mathrm{NH}_{2}$ and (aminooxy)acetic acid was dissolved in eluent $\mathrm{A}$ and separated by RP-HPLC. The solvent of the collected (aminooxy)acetylated peptide fraction was evaporated in a weighed flask. The product was dissolved in $0.2 \mathrm{M} \mathrm{NaOAC}$ 


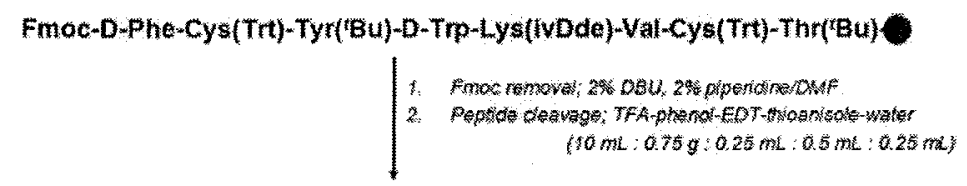

H-D-Phe-Cys-Tyr-D-Trp-Lys(ivDde)-Val-Cys-Thr-NH

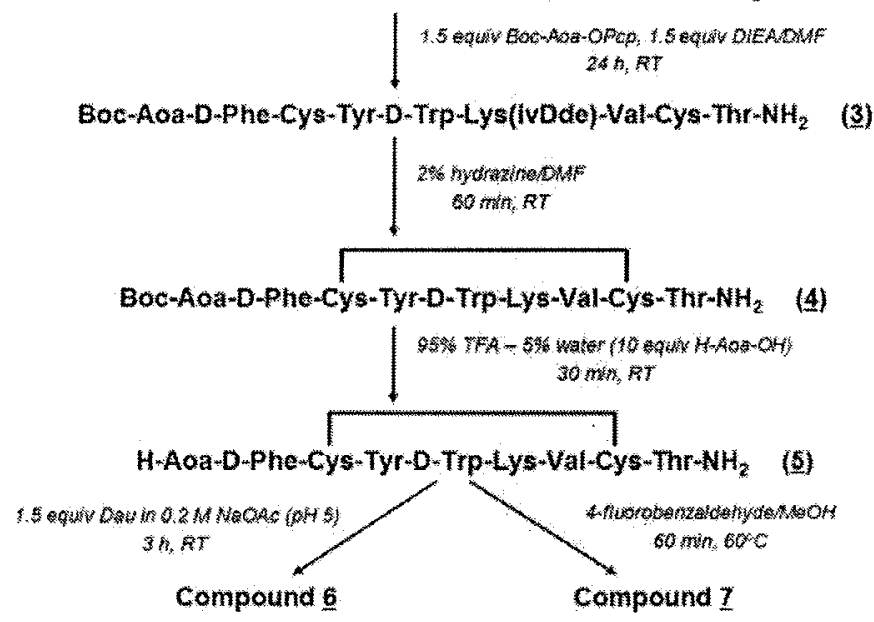

Scheme 1. Outline of the synthesis of daunorubicin-and FBOA-somatostatin conjugates.

(pH 5.0) and 50\% excess of Dau was added to the solution (the oxime ligation was carried out for $3 \mathrm{~h}$ ). The oxime bond containing Dau-peptide conjugate was formed almost quantitatively. The excess of Dau was separated from the conjugate by RP-HPLC. The oxime bond-linked Dau-somatostatin conjugate was characterized by analytical HPLC (Rt: $31.5 \mathrm{~min}$ ) and ESI-MS $\left(M_{\text {calc/xp }}: 1628.0 / 1628.1\right)$.

\section{Oxime ligation of 4-fluorobenzaldehyde to Aoa-somatostatin derivative (FBOA-D-Phe-c[Cys-Tyr-D-Trp-Lys-Val-Cys]-Thr- $\mathrm{NH}_{2}$, 7)}

A mixture of $10 \mathrm{mg}$ somatostatin analog and Aoa was dissolved in $0.8 \mathrm{ml}$ of $0.1 \%$ TFA (aqueous solution). The peptide was immobilized on a Sep-Pak Plus C18 cartridge and the cartridge was flushed with $8 \mathrm{ml}$ of $0.1 \%$ TFA in water. The peptide was eluted with $75 \% \mathrm{MeOH} / 0.1 \%$ TFA. The first fraction $(0.6 \mathrm{ml})$ was discarded and the fractions containing the peptide analog were combined $(1 \mathrm{ml})$. A solution of $0.62 \mathrm{mg}$ 4-fluorobenzaldehyde in $25 \mu \mathrm{MeOH}$ was added $(5 \mu \mathrm{mol})$ to this mixture and stirred for $60 \mathrm{~min}$ at $60^{\circ} \mathrm{C}$. The solution was cooled down to room temperature and then diluted with water to a final volume of $5 \mathrm{ml}$. The labeled peptide analog was purified by semipreparative RP-HPLC. The purity was higher than $97 \%$ and the amount of purified peptide conjugate that resulted was $3.2 \mathrm{mg}$. The yield could not be calculated due to the unknown composition of the starting mixture of the somatostatin analog and Aoa. The conjugate was characterized by analytical HPLC (Rt: $12.9 \mathrm{~min}$ ) and MALDI-MS (MW calc/ exp: 1224.5/1224.6)

\section{High performance liquid chromatography (HPLC)}

Analytical RP-HPLC was performed on a Knauer (H. Knauer, Bad Homburg, Germany) system using a Phenomenex Jupiter C18 column $(250 \mathrm{~mm} \times 4.6 \mathrm{~mm}$ ) with $5 \mu \mathrm{m}$ silica ( $300 \AA$ pore size) (Torrance, $C A$ ) as a stationary phase. Linear gradient elution ( $0 \mathrm{~min}$ $0 \% \mathrm{~B} ; 5 \mathrm{~min} 0 \% \mathrm{~B} ; 50 \mathrm{~min} 90 \% \mathrm{~B})$ with eluent $\mathrm{A}(0.1 \%$ TFA in water $)$ and eluent $B[0.1 \%$ TFA in acetonitrile-water $(80: 20, v / v)]$ was used at a flow rate of $1 \mathrm{ml} / \mathrm{min}$. Peaks were detected at $\lambda=220 \mathrm{~nm}$. The crude products were purified on a semipreparative Phenomenex Jupiter C18 column $(250 \mathrm{~mm} \times 10 \mathrm{~mm})$ with $10 \mu \mathrm{m}$ silica $(300 \AA$ pore size). For purification, methanol-water $(90: 10, \mathrm{v} / \mathrm{v})$ solvent mixture was used at a flow rate of $4 \mathrm{ml} / \mathrm{min}$. However, in the case of Boc-Aoa-somatostatin derivatives, $0.1 \%$ TFA in acetonitrile-water $(80: 20, v / v))$ was used as eluent $B$.

For the purification of FBOA-somatostatin derivative, Waters ${ }^{(*)}$ Xterra MSC18 $(50 \mathrm{~mm} \times 10 \mathrm{~mm}), 2.5 \mu \mathrm{m}$ column (Milford, MA) was used. Linear gradient elution ( $0 \mathrm{~min} 15 \% \mathrm{~B} ; 2 \mathrm{~min} 15 \% \mathrm{~B} ; 15 \mathrm{~min}$ $60 \% \mathrm{~B})$ with eluent $A[0.1 \%$ TFA in acetonitrile-water $(5: 95, \mathrm{v} / \mathrm{v})]$ and eluent $B[0.1 \%$ TFA in acetonitrile-water $(95: 5, v / v)]$ was used at a flow rate of $2 \mathrm{ml} / \mathrm{min}$. The purity of the FBOA-somatostatin conjugate was determined by analytical HPLC using Supelco Discovery ${ }^{\text {ii }}$ Bio Wide Pore C18 $(150 \times 2.1 \mathrm{~mm}), 5 \mu \mathrm{m}$ (Supelco, Sigma-Aldrich, Bellefonte, PA). The same eluents were used with the following gradient elution: $0 \mathrm{~min} 15 \% \mathrm{~B}, 2 \mathrm{~min} 15 \% \mathrm{~B}, 15 \mathrm{~min}$ $60 \% \mathrm{~B}$. The flow rate was $0.35 \mathrm{ml} / \mathrm{min}$.

\section{Mass spectrometry (MS)}

Mass spectrometric analyses were carried out on a Bruker Daltonics Esquire $3000+$ ion trap mass spectrometer (Bremen, Germany). Spectra were acquired in the $50-2000 \mathrm{~m} / \mathrm{z}$ range. Samples were dissolved in acetonitrile-water $=1: 1(\mathrm{v} / \mathrm{v})$ solvent mixture containing $0.1 \%$ acetic acid.

The mass spectrometric analysis of FBOA-somatostatin conjugate was performed on a Bruker Biflex-III MALDI-TOF mass spectrometer (Bremen, Germany) using 2,5-dihydroxy benzoic acid (DHB) as a matrix.

\section{Cells}

MCF-7 human breast adenocarcinoma cell line was maintained in DMEM (Sigma Ltd. St. Louis, MO) containing 10\% FCS (fetal calf 
A

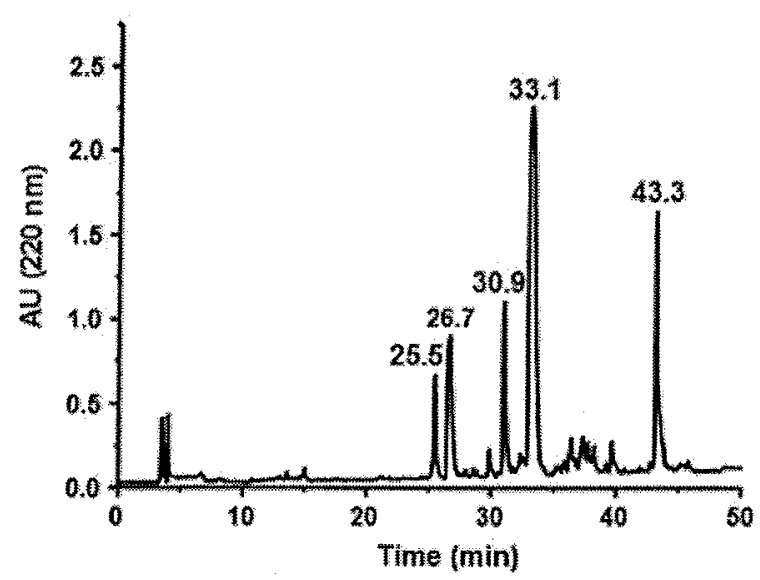

0

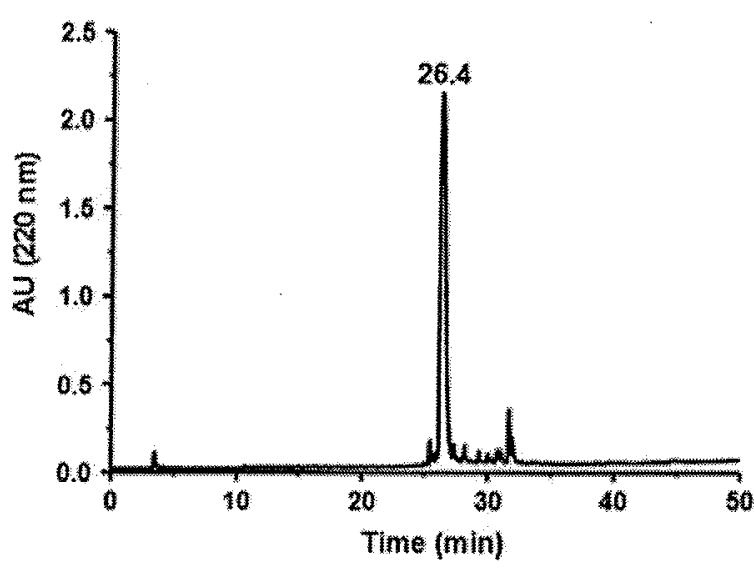

$B$

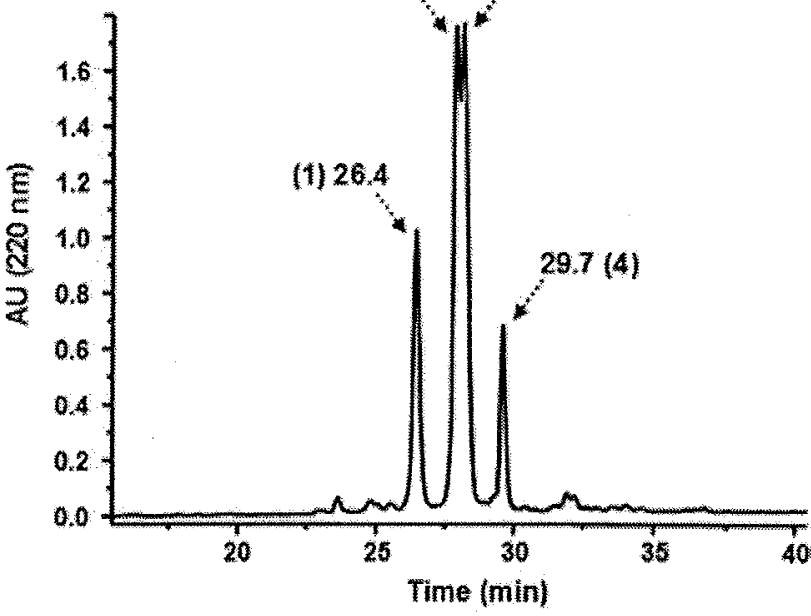

$\mathrm{D}$

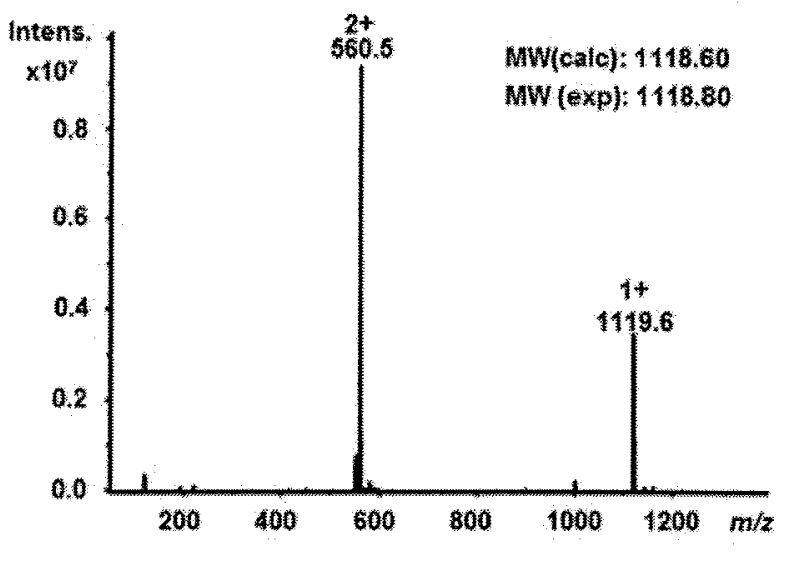

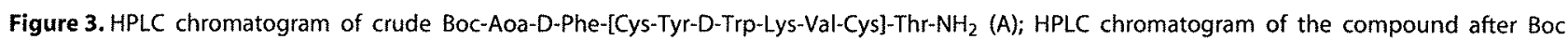
cleavage in the absence of free Aoa (B); HPLC chromatogram of the compound after Boc cleavage in the presence of 10 equiv. free Aoa (C); ESI-ion trap mass spectrum of H-Aoa-D-Phe-[Cys-Tyr-D-Trp-Lys-Val-Cys]-Thr- $\mathrm{NH}_{2}$ (D)

serum, Sigma Ltd.), L-glutamine $(2 \mathrm{~mm})$, gentamicin $(160 \mu \mathrm{g} / \mathrm{ml})$ at $37^{\circ} \mathrm{C}$ in a humidified $5 \% \mathrm{CO}_{2}$ atmosphere. HT-29 human colon adenocarcinoma cell line was cultured in RPMI-1640 (Sigma Ltd.) containing $10 \% \mathrm{FCS}$, L-glutamine (2 $\mathrm{mm})$, and gentamicin $(160 \mu \mathrm{g} / \mathrm{ml})$ at $37^{\circ} \mathrm{C}$ in a humidified $5 \% \mathrm{CO}_{2}$ atmosphere. $\mathrm{NCl}$. H358 human non-small cell lung cancer cell line was maintained in RPMI- 1640 containing $10 \% \mathrm{FCS}$ and L-glutamine $(2 \mathrm{mM})$ at $37^{\circ} \mathrm{C}$ in a humidified $5 \% \mathrm{CO}_{2}$ atmosphere.

In vitro cytostatic effect of compound 6 determined by MTT assay (3-(4,5-dimethylthiazol-2-yl)-2,5-diphenyltetrazolium bromide assay)

To study the in vitro cytostatic effect of compound 6, MCF-7 human breast, HT-29 human colon and NCI-H358 human non-small cell lung cancer cells were plated into 96-well tissue-culture plate in $100 \mu \mathrm{l}$ culture medium with the initial cell number of $5 \times 10^{3}$ cells/well. The compounds used in the $5 \times 10^{-4}-2 \times 10^{2} \mu \mathrm{m}$ concentration range were dissolved in fresh culture medium and added to the cells. After treatment and incubation $(6 \mathrm{~h}$ in case of NCI-H358 cells or $16 \mathrm{~h}$ in case of MCF-7 and HT-29 cells) at $37^{\circ} \mathrm{C}$, cells were washed twice with serum-free medium and cultured in serum-containing medium for $72 \mathrm{~h}$. The amount of the living cells was determined by MTT assay using $0.367 \mathrm{mg} / \mathrm{ml}$ final concentration of MTT in each well. After $3.5 \mathrm{~h}$ incubation with $M T T$, cells were centrifugated at $2000 \mathrm{rpm}$ for $5 \mathrm{~min}$, supernatant was removed and crystals were dissolved in DMSO. The absorbance was measured using an ELISA-reader (Labsystems MS Reader, Finland) at $\lambda=540 \mathrm{~nm}$ and at $\lambda=620 \mathrm{~nm}$ as reference wavelength. Statistical data analysis was performed by Student's $t$-test of Origin 7.5 at the $95 \%$ confidence level.

\section{Results and Discussion}

Hormonal peptides such as somatostatin, $\mathrm{GnRH}$, and their derivatives are applied for targeting drugs and radionuclides to cancer cells $[24,25]$. One approach to attach drugs or isotope-containing organic compounds to peptides is oxime ligation between an (aminooxy)acetylated peptide and an oxo group. However, the sensitivity of the aminooxy moiety to other oxo group containing compounds like acetone, formaldehyde and so on makes 

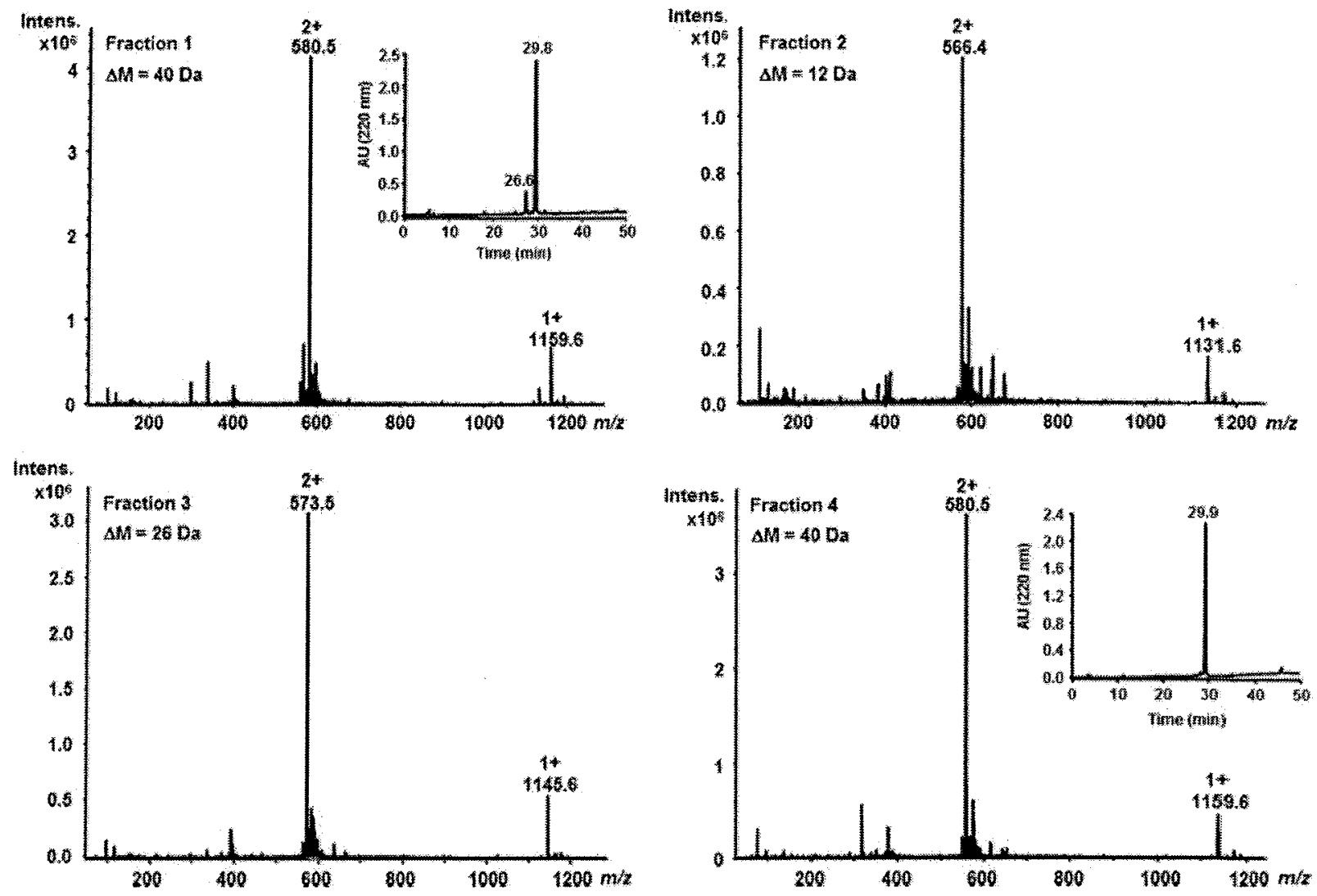

Figure 4. ESI-ion trap mass spectra of the HPLC fractions obtained after the separation of the reaction mixture derived from Boc deprotection in the absence of Aoa.

the synthesis and storage of Aoa-peptides difficult. The major goal of our work was to prepare oxime bond-linked daunorubicin-somatostatin and FBOA-somatostatin conjugates for targeted cancer chemotherapy and positron emission tomography (PET) (Figure 1) using daunorubicin or 4-fluorobenzaldehyde and H-Aoa-D-Phe-c[Cys-Tyr-D-Trp-Lys-Val-Cys]-Thr- $\mathrm{NH}_{2}$, an N-terminal Aoa-elongated version of RC-121 somatostatin analog. For this purpose, the peptide was initially purchased from a supplier; however, the received compound had a molecular mass with 40 Da higher than the calculated one, modification that might derive from the oxime bond formation between acetone and Aoa-peptide (according to the literature data [10]). Therefore, we decided to synthesize the peptide by ourselves.

The somatostatin analog was built up by SPPS on a Rink-Amide MBHA resin followed by the cleavage with TFA in the presence of appropriate scavengers and reducing agents (water, phenol, thioanisole, EDT). Surprisingly, the crude product obtained after lyophilization (liquid nitrogen was used for freezing the sample) was characterized by one main HPLC peak corresponding to the acetone-modified peptide ( $M+40$ Da mass). In the next trial, the somatostatin derivative without Aoa was prepared using ivDde protecting group on the side chain of Lys (Figure 2). The peptide was cyclized by air oxidation, followed by the coupling of Boc-Aoa$\mathrm{OH}$ to the cyclic peptide using BOP reagent. The reaction resulted in the Aoa-containing cyclic somatostatin derivative with a very low yield. Finally, Boc-Aoa-OPcp prepared in our laboratory was connected to the linear semiprotected peptide chain (Boc-AoaD-Phe-Cys-Tyr-D-Trp-Lys(ivDde)-Val-Cys-Thr-NH${ }_{2}$ ) (Scheme 1). The cleavage of ivDde protecting group with $2 \%$ hydrazine in DMF resulted not only in the removal of the protecting group but also in the cyclization of the somatostatin derivative (Figure 3(A); compound with a retention time of $33.1 \mathrm{~min}$ ). The Boc group from the cyclic compound was cleaved with TFA in the presence of $5 \%$ water using argon flushed glass wears followed by precipitation with diethylether. The RP-HPLC profile of the crude product after lyophilization showed four peaks that corresponded to the expected cyclic peptide ( $R$ t: $26.4 \mathrm{~min}$ ) and oxime derivatives with $+12 \mathrm{Da}$, $+26 \mathrm{Da}$, and +40 Da molecular masses (Figures $3(\mathrm{~B})$ and 4). The crude peptide was purified by RP-HPLC using methanol as a major component of eluent B. However, the separated fraction corresponding to the expected product (fraction 1, Rt: $26.4 \mathrm{~min}$ ) turned to the acetone-modified one very fast and no other compound could be detected by MS after lyophilization (Figure 4). The chemical modification of the expected product was also confirmed by the change of the retention time (Rt: $29.8 \mathrm{~min})$, which was identical with that of the acetone-modified compound (fraction 4, Figure 4). To overcome the unwanted oxime bond formation under the cleavage conditions and during the work-up procedure, 10 equiv. of free (aminooxy)acetic acid were added to the cleavage mixture used to remove the Boc group of the cyclic somatostatin derivative (Scheme 1). The HPLC profile of the resulted crude product showed only one main peak (Figure $3(C)$ ) which corresponded to the expected product as determined by mass spectrometry (Figure 3(D)). The work-up procedure (precipitation with dry diethylether, solubilization in acetic acid, and lyophilization) did not result in the removal of 


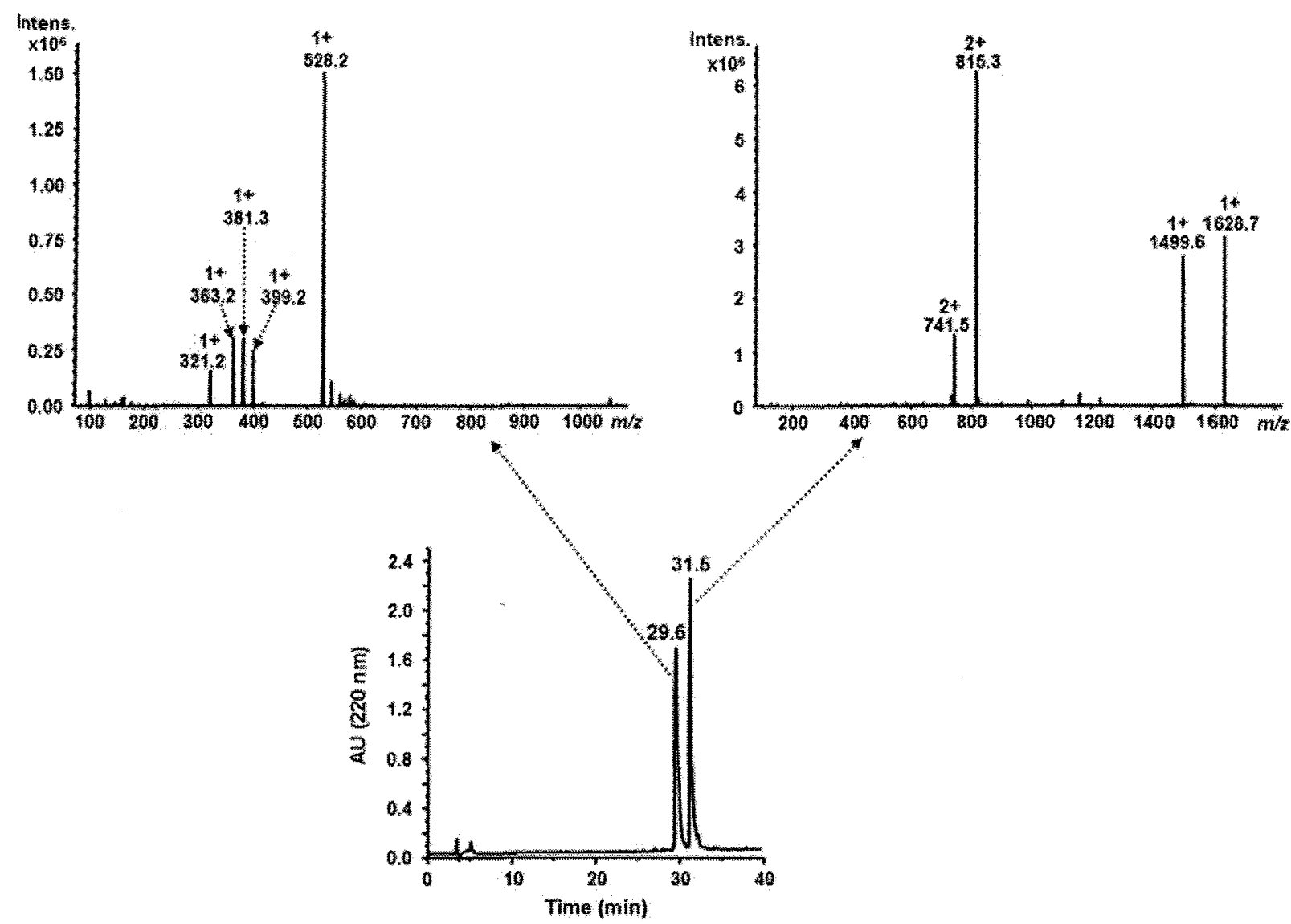

Figure 5. HPLC chromatogram of the reaction mixture of oxime ligation after $3 \mathrm{~h}$ and ESI-ion trap mass spectra of the corresponding HPLC fractions: daunorubicin $\left([\mathrm{M}+\mathrm{H}]^{+*}=528.2 \mathrm{Da}\right)$ and Dau-somatostatin derivative conjugate $\left([\mathrm{M}+\mathrm{H}]^{+}=1628.7 \mathrm{Da}\right)$.

the Aoa excess from the peptide; therefore, the compounds could be kept for months at $+4^{\circ} \mathrm{C}$ without detecting any significant modification. However, the excess of Aoa should be removed prior to the chemical ligation in order to avoid the reaction of carbonyl-containing compounds with free Aoa. For this purpose, the mixture containing Aoa-peptide and free Aoa was purified by RP-HPLC using methanol as eluent $B$, followed by an immediate evaporation of the solvent from the collected peptide fraction. The resulting material was dissolved in $0.2 \mathrm{MNaOAC}, \mathrm{pH}=5$ and added to daunorubicin. The ligation was completed in $3 \mathrm{~h}$ (Figure 5; it is also important to note the fragmentation of the glycosidic bond during the mass spectrometric analysis resulting in the loss of daunosamine).

In another application, the peptide was dissolved in $0.1 \%$ TFA (aqueous solution) and immobilized on a Sep-Pak ${ }^{\text {Pi }}$ Plus C18 cartridge. The somatostatin derivative was eluted with $75 \%$ $\mathrm{MeOH}$ solution containing $0.1 \%$ TFA and the peptide containing fraction was mixed directly with the $\mathrm{MeOH}$ solution of 4fluorobenzaldehyde. The ligation continued at $60^{\circ} \mathrm{C}$ for $60 \mathrm{~min}$ resulting in the expected FBOA-somatostatin derivative.

Invitro cytostatic activity of oxime bond-linked daunorubicin-somatostatin conjugate was determined on MCF-7 human breast, HT-29 human colon, and NCl-H358 human lung cancer cell lines by MTT assay. The cytostatic effect of the daunorubicin-somatostatin conjugate (presented as $I C_{50}$ values in Table 1) was one order of magnitude lower on all investigated cell types
Table 1. Cytostatic effect (IC5 values) of the oxime bond inked daunorubicin somatostatin conjugate 6 on various cancer cell Ines

\begin{tabular}{|lcc|} 
Cell line & $\begin{array}{c}\text { Dau-somatostatin } \\
\text { conjugate (6) }\end{array}$ & Daunorubicin \\
\hline MCF-7 & $4.3 \mu \mathrm{M}$ & $0.2 \mu \mathrm{M}$ \\
HT-29 & $20.6 \mu \mathrm{M}$ & $2.0 \mu \mathrm{M}$ \\
NCI-H358 & $4.5 \mu \mathrm{M}$ & $0.3 \mu \mathrm{M}$ \\
\hline
\end{tabular}

$(1-20 \mu \mathrm{M})$ than that of free daunorubicin $(0.1-2 \mu \mathrm{m})$. The data are similar to those obtained in the case of oxime bond containing Dau-GnRH-III conjugates $[13,26]$ that have been already shown to have in vivo antitumor effect without significant toxic side effects. The results reported here are promising and provide a basis for the further investigation of the in vivo antitumor activity of this novel Dau-somatostatin conjugate.

\section{Conclusions}

Oxime ligation is a chemoselective procedure most commonly used for the preparation of peptide conjugates. However, the sensitivity of (aminooxy)acetylated peptides to ketones and aldehydes makes their synthesis and storage difficult. Therefore, in order to prevent the unwanted modifications of highly sensitive 
Aoa-peptide derivatives, we investigated the application of free (aminooxy)acetic acid as a 'carbonyl capture' reagent to be used in the final cleavage step and during the work-up procedure and storage. In the presence of free (aminooxy)acetic acid, an Aoa-somatostatin derivative could be efficiently prepared and used for further chemoselective ligation with daunorubicin and 4-fluorobenzaldehyde leading to the formation of conjugates with potential applications in targeted cancer chemotherapy and PET. The oxime bond-linked daunorubicin-somatostatin conjugate has in vitro cytostatic activity on various cancer cell lines, such as MCF-7 human breast, HT-29 human colon, and NCI-H358 human lung cancer cell lines.

\section{Acknowledgements}

This study was supported by grants from the Hungarian National Science Fund (OTKA NK 77485, F 67884, K81596), the University of Konstanz (Zukunftskolleg, Project 879/08), and GVOP-3.2.1.-200404-0005/3.

\section{References}

1 Rose K. Facile synthesis of homogeneous artificial proteins. J. Am. Chem. Soc. 1994: 116: 30-33.

2 Shao J, Tam JP. Unprotected peptides as building blocks for the synthesis of peptide dendrimers with oxime, hydrazone, and thiazolidine linkages. J. Am. Chem. Soc 1995; 117: 3893-3899.

3 Thumshirn G, Hersel U, Goodman SL, Kessler H. Multimeric cyclic RGD peptides as potential tools for tumor targeting: solid-phase synthesis and chemoselective oxime ligation. Chem. - Eur. J. 2003; 9: 2717-2125.

4 Cremer GA, Bureaud N, Lelièvre D, PillerV, PillerF, Delmas A. Synthesis of branched oxime-linked peptide mimetics of the MUC1 containing a universal T-helper epitope. Chem. - Eur. J. 2004; 10: $6353-6360$.

5 Renaudet 0 , Dumy P. Chemoselective template-assembled glycoconjugates as mimics for multivalent presentations of carbohydrates. Org. Lett. 2003; 5: 243-246.

6 Dey S, Sheppard TL. Ketone-DNA: a versatile postsynthetic DNA decoration platform. Org. Lett. 2001; 3: 3983-3986.

7 Hamma T, Miller P5. 4-(2-Aminooxyethoxy)-2-(ethylureido)quinoline-oligonucleotide conjugates: synthesis, binding interactions, and derivatization with peptides. Bioconjugate Chem. 2003 14:320-330.

8 Zatsepin TS, Stetsenko DA, Arzumanov AA, Romanova EA, Gait MJ, Oretskaya TS. Synthesis of peptide-oligonucleotide conjugates with single and multiple peptides to 2[prime]-aldehydes through thiazolidine, oxime, and hydrazine linkages. Bioconjugate Chem. 2002; 13: 822-830.

9 Canne LE, Ferré-D'Amaré AR, Burley SK, Kent SBH. Total chemical synthesis of a unique transcription factor-related protein: CMyc-Max. J. Am. Chem. Soc. 1995; 117: 2998-3007.

10 Buré $C$, Levièvre D, Delmas A. Identification of by-products from an orthogonal peptide ligation by oxime bonds using mass spectrometry and tandem mass spectrometry. Rapid Commun. Mass Spectrom. 2000; 14: 2158-2164.

11 Poethko T, Schottelius M, Thumshirn G, Hersel U, HerzM,

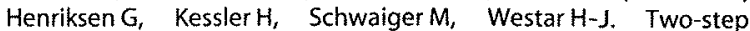
methodology for high-yield routine radiohalogenation of peptides: ${ }^{18} \mathrm{~F}$-labeled RGD and octreotide analogs. J. NuCl. Med. 2004; 45: 892-902.

12 Schottelius M, Berger S, Poethko T, Schwaiger M, Westar H-J. Development of novel ${ }^{68} \mathrm{Ga}$ - and ${ }^{18} \mathrm{~F}$-labeled $\mathrm{GnRH}-\mathrm{I}$ Analogues with high GnRHR-targeting efficiency. Bioconjugate Chem. 2008; 19: $1256-1268$.

13 Szabó I, Manea M, Orbán E, Csámpai A, Bosze Sz, Szabó R, Tejeda M, Gaál D, Kapuvári B, Przybylski M, Hudecz F, Mezo G. Development of oxime bond containing daunorubicin-gonadotropin-releasing hormone-III conjugate as a potential anticancer drug. Bioconjugate Chem. 2009; 20: 656-665.

14 Ingallinella P, Di Marco A, Taliani M, Fattori D, Pessi A. A new method for chemoselective conjugation of unprotected peptides to Daunoand Doxorubicin. Bioorg. Med. Chem. Lett. 2001; 11:1343-1346.

15 Miklán Z, Orbán E, Csík G, Schlosser G, Magyar A, Hudecz F. New daunomycin-oligoarginine conjugates: synthesis, characterization, and effect on human leukemia and human hepatoma cells. Biopolymers 2009; 92: 489-501.

16 Kubler-Kielb J, Pozsgay V. A new method for conjugation of carbohydrates to proteins using an aminooxy-thiol heterobifunctional linker. J. Org. Chem. 2005; 70:6987-6990.

17 Singh $Y$, Spinelli N, Defrancq E, Dumy P. A novel heterobifunctional linker for facile access to bioconjugates. Org. Biomol. Chem. 2006; 4: 1413-1419.

18 Decostaire IP, Levièvre D, Zhang HH, Delmas AF. Controlling the outcome of overacylation of $\mathrm{N}$-protected aminooxyacetic acid during the synthesis of an aminooxy-peptide for chemical ligation. Tetrahedron Lett. 2006; 47: 7057-7060.

19 Foillard S, Rasmussen MO, Razkin J, Boturyn D, Dumy P. 1-Ethoxyethylidene, a new group for the stepwise SPPS of aminooxyacetic acid containing peptides. J. Org. Chem. 2008; 73: 983-991.

20 Jimenez-Castells C, de la Torre BG, Gallego RG, Andreu D. Optimized synthesis of aminooxy-peptides as glycoprobe precursors for surface-based sugar-protein interaction studies. Bioorg. Med. Chem. Lett. 2007; 17: 5155-5158.

21 Galibert M, Dumy P, Boturyn D. One-pot approach to well-defined biomolecular assemblies by orthogonal chemoselective ligations. Angew. Chem., Int. Ed. Engl. 2009; 48: 2576-2579.

22 Carulla N, Woodward C, Barany G. Toward new designed proteins derived from bovine pancreatic trypsin inhibitor (BPTI): covalent cross-linking of two 'core modules' by oxime-forming ligation. Bioconjugate Chem. 2001; 12: 726-741.

23 Cai RZ, Szoke B, LuR, FuD, Redding TW, Schally AV. Synthesis and biological activity of highly potent octapeptide analogs of somatostatin. Proc. Natl. Acad. Sci. U.S.A. 1986; 83: 1896- 1900.

24 Schally AV, Nagy A. Chemotherapy targeted to cancers through tumoral hormone receptors. Trends Endocrinol. Metab. 2004; 15 $300-310$.

25 Mezo G, Manea M. Receptor-mediated tumor targeting based on peptide hormones. Expert Opin. Drug Deliv. 2010; 7:79-96.

26 Mezo G, Manea M, Szabó I, Vincze B, Kovács M. New derivatives of GnRH as potential anticancer therapeutic agents. Curr. Med. Chem. $2008 ; 15: 2366-2379$ 